\section{Rettferdig bruk av kostnadsdata}

Høykostnadsmedisin gir store utfordringer når det gjelder rettferdig fordeling av helsegevinster. Helseøkonomiske evalueringer er i så måte et viktig teknisk hjelpemiddel for å tydeliggjøre helsekostnadene og for å kunne gjøre rettferdige prioriteringer på tvers av pasientgrupper. Standard helsemål i slike evalueringer er kostnad per vunnet leveår eller kvalitetsjusterte leveår (QALY) (1).

I Nordermoen \& Bratlids artikkel konkluderte de med at «behandling av nyfødte med fødselsvekt $<1000 \mathrm{~g}$ er svært kostbart» - fordi det koster 900000 kroner per pasient (2). De får støtte av Frøisland på lederplass i at «prematuritetsmedisinen er kostnadisintensiv». Men hvis vi regner med at en nyfødt lever i 80 år, blir kostnaden per vunnet leveår 11250 kroner. Få medisinske intervensjoner er så kostnadseffektive totalt sett. Konklusjonen blir derfor feil når Nordermoen \& Bratlid sier at de premature er den dyreste pasientgruppen i norske sykehus. Nasjonalt råd for kvalitet og prioritering fraråder å innføre medisinsk teknologi som koster mer enn 425000 kroner per vunnet leveår. Vi har derfor råd til å behandle denne pasientgruppen i Norge.

Forfatterne skriver også at det foreligger få internasjonale data som kan gi et komplett kostnadsbilde. Men det finnes flere studier der både behandlingskostnader og fremtidige kostnader er dokumentert (3-5). Mangham og medarbeidere beskrev kostnadene for ekstremt premature barn i England og Wales fra fødselen til de er 18 år (6). Kostnadene knyttet til senere oppfølging var svært lav, 92,4\% av den totale ressursbruken tilskrives den første sykehusinnleggelsen. Forskjellen i totalkostnad mellom ekstremt premature (svangerskapsalder $<28$ uker) og barn født til termin var også lav: 94740 pund (891 692 kroner).

Vi synes det er bra at norske forskere publiserer kostnadsdata, men vil oppfordre til å formidle dette slik at det blir et relevant innspill i den offentlige prioriteringsdebatten.

\section{Kjell Arne Johansson \\ Ingrid Miljeteig \\ Institutt for samfunnsmedisinske fag \\ Universitetet i Bergen}

\section{Litteratur}

. Robberstad B. QALYs vs DALYs vs LYs gained what are the differences, and what difference do they make for health care priority setting? Norsk Epidemiologi 2005: 15: 183-91.

2. Nordermoen A, Bratlid D. Kostnader ved behandling av svært for tidlig fødte barn. Tidsskr Nor Legeforen 2010; 130: 1130-4

3. Petrou S, Abangmna G, Johnson $G$ et al. Costs and health utilities associated with extremely preterm birth: evidence from the EPICure Study. Value in Health 2009; 12: 1124-34.

4. Korvenranta E, Lehtonen L, Häkkinen $U$ et al. Morbidities and hospital resource use during the first 3 years of life among very preterm infants. Pediatrics 2009; 124: 128-34.
5. Clements K, Barfield WD, Ayadi F et al. Preterm birth-associated cost of early intervention services: an analysis by gestational age. Pediatrics 2007; 119: e866-74.

6. Mangham LJ, Petrou S, Doyle LW et al. The cost of preterm birth throughout childhood in England and Wales. Pediatrics 2009; 123: e312-27.

\section{A. Nordermoen}

\section{\& D. Bratlid svarer:}

I vår artikkel ønsket vi å synliggjøre kostnadene ved behandling av svært premature barn. Ruud Hansen og Johansson \& Miljeteig kobler dette opp mot en annen viktig problemstilling - nemlig prioritering av behandling av ekstremt premature. Vi er langt på vei enige med alle at kostnadene ved denne behandlingen ikke skal tillegges avgjørende betydning når det gjelder prioritering, bl.a. fordi svært mange nå overlever.

Imidlertid dreier dette seg ikke bare om overlevelse. Nesten ingen født i uke 23 og svært få født i uke 24 overlever uten skade (hjerneskade, øyeskade, lungeskade og andre skader). Det er derfor ikke overraskende at diskusjonen om grensene for behandling av små premature er aktualisert. Dette skyldes ikke behandlingskostnadene, men vel så mye spørsmålet om hvilken livskvalitet mange av disse barna overlever til. Den praktiske og psykiske belastningen mange av familiene strever med og de samfunnsmessige konsekvensene av dette er tilleggsmomenter i vurderingen. I mange land er det på denne bakgrunn veiledende restriksjoner i behandlingen av de aller minste, slik en europeisk oversikt viser (1). En spørreundersøkelse blant norske leger har også avdekket en generell oppfatning om at man kanskje er for liberal i å tilby behandling til disse (2).

De fleste oppfølgingsstudier av svært premature som Johansson \& Miljeteig bl.a. viser til inkluderer oftest barn med fødselsvekt $<1000$ gram og eller svangerskapslengde $\leq 28$ uker. Barn født i uke $25 \mathrm{og}$ særlig i uke 26 og senere går det ofte svært bra med, i motsetning til dem som er født i uke 23 og 24, selv om mange overlever, slik Ruud Hansen påpeker. Derfor er grunnlaget for Johansson \& Miljeteigs vurdering av senere kostnader og forventet levetid urealistisk. Det er riktig at de senere medisinske kostnadene ikke er like store som i starten, men utdannings- og habiliteringskostnadene er betydelige. Mange blir også tidlig uføretrygdet. For mange vil derfor totalkostnaden langt overskride de 425000 kroner per vunnet leveår som Johansson \& Miljeteig viser til.

Dette dreier seg etter vår oppfatning ikke bare om kostnader, svangerskapslengde eller vunne leveår, men i større grad om biologi, etikk og jus. I Sverige har man nylig hatt en interessant debatt om disse problemstillingene, der både filosofer, leger og jurister har deltatt (3-7).

Det er positivt dersom vår artikkel kan bidra til at vi får denne debatten også i Norge, selv om det ikke var hensikten med undersøkelsen.

\section{Anja Nordermoen}

Dag Bratlid

Norges teknisk-naturvitenskapelige universitet/ St. Olavs hospital

\section{Litteratur \\ 1. Pignotti MS. Extremely preterm births: recom- mendations for treatment in European countries. Arch Dis Child Fetal Neonatal Ed 2008; 93: F403- F406 \\ 2. Miljeteig I, Markestad T, Norheim OF. Physicians use of guidelines and attitudes to withholding and withdrawing treatment for extremely premature neonates in Norway. Acta Paediatr 2007; 96: $825-9$. \\ 3. Tännsjø T. När ska man försöka rädda dem - och vem ska bestämma? Läkartidningen 2009; 106; 1796-7. \\ 4. Åmark P. Att vårda de extremt underburna - vem ska bestämma? Läkartidningen 2009: 106: 1919. \\ 5jørs G. Även extremt underburna barn har rätt til fullvärdig vård. Läkartidningen 2009: 106: 1988-9. \\ 6. Håkansson S. Beslutet kan inte tas ensidig av föräldrarna. Läkartidningen 2009; 106: 1989-90. \\ . Rynning E. Frågan värd en mer nyanserad diskus- sion. Läkartidningen 2009; 106: 1990-1.}

\section{Av respekt for avdøde}

Anders Svare setter i en kronikk i Tidsskriftet nr. 7/2010 og i et leserinnlegg i nr. 12/2010 spørsmålstegn ved nytten av sykehusobduksjon $(1,2)$. Hans ubegrunnede mening er at det «skal foreligge en meget god grunn til å skjære i døde mennesker». Svare mener åpenbart at det sjelden er en meget god grunn. Etter mange år som patolog i tett dialog med klinikere finner jeg fortsatt at obduksjonen representerer nyttig kvalitetskontroll. Jeg kan ikke forstå Svare annerledes enn at han finner det verdiløst at behandlende lege og avdødes pårørende mottar informasjon om at:

- Kvinnen som i månedsvis ble behandlet for antatt kols, døde av en ikke-diagnostisert kreftsykdom med lungemetastaser

- Mannen som døde en uke etter at det var lagt inn en stent i ramus circumflexus, hadde fått massiv stenttrombose

- Kvinnen med kronisk glomerulonefritt døde av ikke-erkjent miliær tuberkulose

- Den unge mannen som var operert for osteosarkom og døde uventet, hadde ikkeerkjente metastaser, bl.a. til hjertet

- Lungekreftpasienten med flere ukers uforklarlige buksmerter døde av peritonitt som følge av ikke-erkjent perforert appendisitt

- Barnet som døde i mors liv etter sju måneders svangerskap, hadde en alvorlig hjertemisdannelse

I vårt høyt utviklede og teknologiske helsevesen er obduksjonen fortsatt en kilde til faglig ettertanke og en verdifull motgift mot klinisk overmot. Oftere og oftere opplever vi nå at avdødes pårørende ber om at det blir 
obdusert. Av respekt for avdøde bør obduksjon fortsatt gjøres i flest mulig tilfeller.

\section{Bjørn I. Bertelsen}

Haukeland universitetssykehus

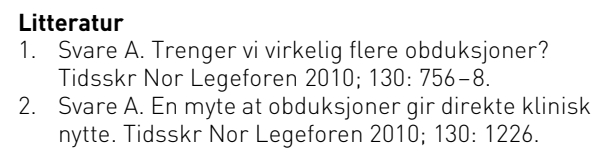

\section{Perioperativ behandling: På sporet av anestesilegene}

Johan Ræder, Per Meinich og Kristin Sem Thagaard har i Tidsskriftet nr. 13-14/2010 interessante kommentarer (1) til min leder Hvor ble det av anestesilegene? (2), der jeg etterlyser en ny tilnærming til organiseringen av den perioperative behandling.

Perspektiv og skott er skjønnsmessige størrelser, men både tradisjon og avstand påvirker virkelighetsbeskrivelsen når det påpekes: «Pasienter på sengepost derimot har tradisjonelt hatt liten plass i anestesiologens hverdag» (1). Dette er utvilsomt sant. Det kan diskuteres hvor klokt det er, men det reflekterer avdelingsstruktur og klassisk arbeidsfordeling mer enn behovet for langsgående deltakelse. Jeg vedholder at det er viktig å sette spørsmålstegn ved om vi egentlig er tjent med at det er slik - og om våre pasienter er det.

Ræder og medarbeidere påpeker at anestesilegen er med i hele det perioperative forløpet ved dagkirurgien. Dette er åpenbart riktig, men det representerer ikke en kvalitativt annerledes organisering. Det perioperative forløpet blir her så kort at det sammenfaller med den avgrensede perioden da anestesilegen uansett er en nøkkelperson i enhver kirurgisk behandling. Dagkirurgi er en intervensjon som passer godt til fagfeltenes organisering, ikke omvendt.

I den tunge kirurgien er smerte og respirasjonsproblemer sentrale postoperative utfordringer som kan vare ved i mange dager, selv etter ukompliserte inngrep. Ofte kan de mest utsatte pasientene identifiseres preoperativt, og optimalisering og forebygging vil være mulig. Dette bildet harmonerer i liten grad med den vanlige organiseringen av våre avdelinger, der ekspertene på «praktisk håndtering av patofysiologiske prosesser og livsviktige funksjoner» (1) i minimal grad er engasjert utover det operative døgnet. I hjertekirurgien - et fag som er jevngammelt med den moderne anestesi - bryter organisering og praktiske arbeidsformer ofte med dette. Uaktet hva slags beveggrunner man hadde eller hvordan det er blitt gjennomført, så representerer det et annerledes perspektiv.

Innflytelse følger av ansvar - ikke omvendt. Ansvar er noe man får, eller bedre: noe man tar. Enhver anestesilege som engasjerer seg langsgående i hele pasientforløpet, vil bli sett som den åpenbare ressurs hun eller han er for kompetansen i den kirurgiske avdelingen og for pasienten. Slike nøkkelpersoner har stor innflytelse og er åpenbare samarbeidspartnere i utviklingen av perioperativ behandling, utdanning og forskning.

\section{Kristoffer Lassen}

Universitetssykehuset Nord-Norge, Troms $\varnothing$

\section{Litteratur}

1. Ræder J, Meinich P, Thagaard KS. Anestesilegene - den som leter skal finne. Tidsskr Nor Legeforen 2010; 130: 1327

2. Lassen K. Hvor ble det av anestesilegene? Tidsskr Nor Legeforen 2010; 130: 720.

\section{Merkelige vitenskapelige begreper}

Helge Drange melder seg i Tidsskriftet nr. 13-14/2010 på i klimadebatten sammen med Gunnar Kvåle (1), men han tar mannen istedenfor ballen. I mitt leserinnlegg (2) viste jeg til en bok utgitt av The Heartland Institute og spesifikt til 35 artikler som hver for seg etter min mening motbeviser påstander fremsatt i Kvåles artikkel (3). Dette avfeies som villedende informasjon fra «en kontroversiell amerikansk tenketank som mottar finansiell støtte fra den amerikanske olje- og kullindustrien»!

Drange/Bjerknessenteret får sine milliarder fra en regjering som med alle midler støtter IPCC s formålsparagraf: A bevise at en menneskeskapt global oppvarming finner sted. Ville Drange protestert dersom hans forskning derfor ble betegnet som «bestillingsarbeid»?

Tom V. Segalstad er etter min mening den mest velinformerte på $\mathrm{CO}_{2}$-området i Norge, men Kvåle \& Drange frakjenner ham enhver legitimitet fordi han benyttes som foredragsholder og medforfatter av The Heartland Institute. Segalstad var norsk representant $\mathrm{i}$ de første arbeidsgruppene hos IPCC, men trakk seg fordi han oppfattet arbeidsmåten som uvitenskapelig.

Kvåle \& Drange påberoper seg «overveldende støtte i faglitteraturen", men kildeangivelse mangler. Phil Jones' (East Anglia University) kommentarer til dagsaktuelle temperaturer forbigår man i taushet. $\mathrm{Og}$ hvor ble det av debatten om alvorlige helseskader grunnet økende global varme?

Referansene i Kvåle \& Dranges litteraturliste inngikk etter det jeg kan se $i$ en politisk offensiv regissert av KYOTOavtalens medlemsland med én ting for øye: Å påvirke prosessen på klimamøtet i København i desember 2009, det som endte med total fiasko.

Det vises til The Fourth Assessment Report of the Intergovernmental Panel on Climate Change 2007. Den delen som er av betydning er «sammendrag for politikere».
Her er vitenskapen forlatt og politisk konsensus har overtatt. Deres referanser nr. 3 og nr. 4 er to selverklærte politiske støtteutspill for København-møtet.

Klimamøtet i desember 2009 var en del av de industrialiserte Kyoto-lands forsøk på å overta styringen av resten av verdens energiregimer. Forblindet av tro på egen fortreffelighet forsto de ikke at de var dømt til å mislykkes før deres forhandlere sto avkledd som makt- og kraftløse.

«Menneskeskapt klimaendring er nå uomtvistelig» sies i deres referanse nr. 3 . På et seminar i regi av Seminaret i vitenskapsteori ved Universitetet i Oslo 2.6. 2010 slo nobelprisvinner Ivar Giæver fast at surt regn, ozonhull og global oppvarming var merkelige vitenskapelige begreper. Bevisene er omstridt og de mulige konsekvenser ukjente. Allikevel sier man at bevisene er uomtvistelige. Mens man kan diskutere protoners faste masse, om der er partikler med større hastighet enn lysets eller om universets ekspansjon er økende, hevder man at menneskeskapt global oppvarming er et ubestridelig faktum.

\section{Svenn Korseth sr.}

Klimarealistene

\section{Litteratur}

1. Kvåle G, Drange H. Klima og helseskader. Tilsvar. Tidsskr Nor Legeforen 2010: 130: 1328.

Korseth S. Klima og helseskader. Tidsskr Nor Legeforen 2010; 130: 1328.

3. Kvåle G. Klimaendringer gir helseskader. Tidsskr Nor Legeforen 2010; 130: 723.

\section{Forsidebildet - hva skjer 'a?}

Vi har alle forskjellige interesser. Noe av det jeg har likt veldig godt med Tidsskriftet, har vært forsidebildet - det har vært et friskt pust. Forsiden har vært et signal om at medlemsmassen vår driver med mye annet enn det vi gjør på jobben. Det har gjort meg stolt.

Det kan ikke bare være meg som har latt Tidsskrift for Den norske legeforening ligge på stuebordet til allmenn fremvisning. Det har kledd enhver anledning. Av og til har forsidebildet gjort at noen som ellers aldri ville ha åpnet det - gjester, barn i familien eller venner - har latt seg friste til å ta en titt inni.

De estetiske bildene har satt Tidsskriftet litt på siden av det hverdagslige. For meg har det vært ikonet som utad speiler det solide faglige innholdet inni. Det har vært historiske bilder eller bilder som er forankret i profesjon eller forening. På finurlig vis har bildet ofte hatt relasjon til innholdet, men på en kreativ og kunstnerisk måte.

Av og til har jeg fnyst av de amatørmessige og direkte uestetiske forsidebildene til andre fagtidsskrifter, som f.eks. Sykepleien, som også ligger hjemme hos meg. Ikke sjelden har vi måttet snu det opp-ned for 